\title{
The Legal Position of Legal Subjects's Civil Rights Due to Overlapping Lands
}

\author{
Rahadiyan Veda Mahardika ${ }^{1} \quad$ Bhim Prakoso $^{2}$ Iswi Hariyani ${ }^{3}$ \\ 1. Students at Faculty of Law, University of Jember \\ 2. Doctorate and Lecturer at Faculty of Law, University of Jember \\ 3. Lecturer at the Faculty of Law, University of Jember
}

\begin{abstract}
Indonesia is well-known as an agricultural country rich of natural resources. This resource is easily developed to support investment climate, especially the plantation sector. The state provides opportunities for legal subjects to invest in the plantation sectors by applying license to control and cultivate private land under the Right to Cultivate (hereinafter referred to as HGU) as stipulated in Article 28 of Act No. 5 of 1960 on Basic Agrarian Act (hereinafter referred to as UUPA). The application for HGU is carried out based on statutory regulation, it aims at providing legal certainty for legal subjects who apply for their rights to the state. The permit issued by the state for land use is a form of granting civil rights for legal subject applicants. Each HGU application is expected to avoid the occurrence of legal dispute. However, a problem often rises due to this application, namely overlapping of lands.
\end{abstract}

Keywords: Civil rights, legal subjects, overlapping land

DOI: $10.7176 / \mathrm{JLPG} / 106-08$

Publication date: February $28^{\text {th }} 2021$

\section{INTRODUCTION}

As a state of law, all Indonesian government administration shall be based on legal principles stipulated in the 1945 Constitution of the Republic of Indonesia as the highest constitutional foundation containing the main rules and regulations for exercising the state power. ${ }^{1}$ The 1945 Constitution is a guideline to achieve the goals idealized by the state as reflected in the values of Pancasila. Article 33 Paragraph 3 of the 1945 Constitution places the responsibility of the state in ensuring public welfare. The attainment of general welfare can be realized due to proper utilizations of the earth, water and natural resources functions for the seeks of the People's prosperity.

It is impossible for all Indonesians to manage the exploitation of natural resources in Indonesia. Regarding its implementation, the Indonesian people as rights holders and bearers of this mandate granted the authority to the State as the whole people's organization of powers. The state is able to control and direct the functions of the earth, water and airspace in line with government policies. 2 As stipulated in Article 2 paragraph 1 of the UUPA the right to control the state is rooted in the Indonesian Nation's Rights, which in essence is implementation of the duties controls on the nation's authority containing elements of public law. The Indonesia natural resource is potential for investment, especially on the plantation and mining sectors. Under proper management, this investment will contribute to national economic development.

The state provides opportunities for individuals and legal entities wishing to invest in plantations and mining sectors by applying for permits to manage the private land with the status of the Right to Cultivate (hereinafter referred to as HGU). This right as regulated in article 28 paragraph 1 of the UUPA is the right to work on land directly controlled by the state for agricultural, fishery, or Animal Husbandry Company. The HGU is granted on land with at least 5 (five) hectares area and a period of time for 25 years to 35 years depending on the commodity. Furthermore, granting permission by the state to manage the land constitutes the granting of civil rights to the applicant.

Applications for HGU are submitted in written form by Indonesian citizens or legal entities through the local Land Office. A Decree of Granting Rights (hereinafter referred to as SKPH) is issued by the Ministry of Agrarian Affairs and Spatial Planning/ National Land Agency (hereinafter referred to as ATR/BPN) or the Head of BPN Regional Office. The SKPH shall be registered and being valid since it is registered to the Land Book by the Land Office, then certificate is issued as an evidence for HGU holder for land use rights. The issuance of Ministerial Decree or the head of the BPN Regional Office indicates a transfer of rights from the state to the legal subjects. Article 14 paragraph 1 of the Government Regulation number 40 of 1996 on Right to Cultivate, Right to Build, and Right to Use Land stipulated that the HGU holders have the right to control and use the land for agricultural, plantation, fishery, and animal husbandry business.

\footnotetext{
${ }^{1}$ Jeffry Alexander Ch. Likadja, Memaknai “Hukum Negara (Law Through State)” dalam Bingkai” Negara Hukum (Rechtstaat)”, Jurnal Hassanudin Law Review, Vol 1 No. 1, 2016, p. 76

${ }^{2}$ Bachtiar Efendie, Kumpulan Tulisan Tentang Hukum Tanah, (Bandung: Alumni, 1993), pp. 1-3.
} 
Legal subjects are obliged to cultivate the HGU land granted to them in accordance with its business feasibility. Based on the SKPH registered to the land book, even without the issuance of HGU certificate, the legal subjects has the right to control over the land. According to Subekti, Right to control over land is a state of birth where a person controls an object as if it is their own property which is protected by the law without questioning to whom the property actually belongs to. ${ }^{1}$

The process of granting permits may cause legal disputes, one of which is overlapping of lands. The negligence of the applicant who did not check the status of the land to be applied for caused violation of the civil rights for the control of land rights from the previous legal subject. This case often results in the issuance of a new decision letter of HGU by the Head of the BPN Regional Office. Civil disputes that occur between these parties have created legal uncertainty regarding the land rights. ${ }^{2}$ On the other hand, the incomplete physical and juridical data on land owned by the ATR/BPN Agency as well as real conditions that are different from those recorded are also important factors in the occurrence of land overlapping disputes. The juridical data refers to information of the legal status or control status of land registered by the right holder or the controlling party. Meanwhile, physical data includes information regarding the location, boundaries and area of the registered parcel of land, including information regarding the existence of a building or part of the building on it. This condition indicates that all land parcels have not been registered at the ATR/BPN Office. Based on the report from the Presidential Staff Office (hereinafter referred to as KSP), there were 780 agrarian conflicts related to overlapping lands. ${ }^{3}$ Therefore, the absence of legal certainty on juridical and technical data may violate the basic civil rights of legal subjects and create legal uncertainty on land rights ownership.

Based on these considerations, there are two important legal issues to be answered in this study, namely: 1) what is the legal position of the rights of legal subjects due to overlapping land? 2) What is the legal effect of overlapping land on the rights of the legal subject?

\section{RESEARCH METHODS}

The method used in this research is juridical normative which aims to provide a systematic exposition of the legal rules that govern certain areas of law. It is used to analyze the relationship between one legal rule and another, and to explain difficult parts of the existence of a legal rule relating to the legal position of the subject's civil rights due to overlapping land. The approaches applied are the conceptual approach and statutory approach. This study focuses on two problems; the first part discusses the arrangement and acquisition of land use rights, and the second part discusses the legal consequences of overlapping land on the civil rights of legal subjects.

\section{DISCUSSION RESULTS}

\subsection{Legal Position of Legal Subjects Rights due to Overlapping Land}

Referring to the principle of Indonesia as a rule of law stipulated in Article 1 paragraph 3 of the 1945 Constitution, it can be interpreted that the highest power in the Indonesian state is the law made by the people through representatives. ${ }^{4}$ In exercising its power, the Government shall act in just. The application of the rule of law principle is based on the efforts to protect basic human rights. ${ }^{5}$ Every person is born free and has the same rights regardless of which country the person comes from, it is then reinforced by article 1 of the Civil Code (hereinafter referred to as the Civil Code) which states that "Enjoying rights of citizenship does not depend on state rights." Inherent rights in humans and are fundamental as a gift from God that must be guarded. There is no penalty that can eliminate rights owned by a person.

According to Sudikno Mertokusumo, cited in Ari Hernawan, rights can be interpreted as anything that can provide enjoyment and freedom to legal subjects in exercising them.6 The right to give the power to receive or do something that should be accepted by a legal subject which in principle can be prosecuted forcibly, which gives birth to an authority that focuses on individual interests which is called civil rights. The civil rights can be interpreted as an extension of the concept of rights that gives authority over one legal subject to other both in family relations and in public relations.

Every right can be exercised if a legal subject is capable of bearing it. Legal subjects can be interpreted as every person who has rights and obligations, which give rise to legal authority. The authority referred to is to

\footnotetext{
${ }^{1}$ Rachmadi Usman, Hukum Kebendaan, (Jakarta: Sinar Grafika, 2011) p. 140

${ }^{2}$ Havidz Farizky, Skripsi: Faktor-Faktor Terjadinya Tumpang Tindih Sertipikat Hak Atas Tanah Dalam Pendaftaran Tanah Di Kabupaten

Sukoharjo (Yogyakarta: Universitas Islam Indonesia, 2018), p. 1.

${ }^{3}$ Ratna Puspita, KSP Terima Laporan 780 Kasus Sengketa Tanah, available fromhttps://nasional.republika.co.id/berita/q2pqhn428/kspterima-laporan-780-kasus-sengketa-tanah, [accessed on February 2, 2020 at $02.00 \mathrm{pm}$ )

${ }^{4}$ Khathryna Ihcent Pelealu, Konsep Pemikiran Tentang Negara Hukum Demokrasi dan Hukum Hak Asasi Manusia Pasca Reformasi, Jurnal

Lex Administratum, Vol. 3 No. 7, 2015, p. 106

${ }^{5}$ Haposan Siallagan, Penerapan Prinsip Negara Hukum di Indonesia, Jurnal Sosiohumaniora, Vol. 18 No. 2, 2016, p. 137

${ }^{6}$ Ari Hernawan. Keseimbangan Hak dan Kewajiban Pekerja dan Pengusaha dalam Mogok Kerja, Jurnal Mimbar Hukum Vol. 24 No. 3 ,

2012, p. 419.
} 
have rights and carry out legal actions and the factors that influence them. ${ }^{1}$ Legal science recognizes two kinds of legal subjects, namely people (natuurlijk persoon) and legal entities (rehts persoon). Any Legal subjects who have legal skills can have the authority to have land rights. This right gives the holder the authority to use the surface of the earth, the body of the earth, and water as well as the airspace above it for their interests which is related to the provisions of the UUPA. Legal protection for legal subjects who wish to cultivate natural resources in the territory of the archipelago is provided in the form of land use rights. in the UUPA there are two legal subjects capable of bearing business use rights, namely humans and legal entities.

The use and control of land rights must be in accordance with the regulations as mandated in Article 2 paragraph (2) and (3) of the UUPA which contains the provision that all operations related to the designation, use, maintenance of land supplies must be used to achieve the prosperity of the people. In order to achieve this goal, the state provides equal opportunities for legal subjects to control and manage land in the form of HGU. ${ }^{2}$ Provisions related to these rights are regulated in articles 28 to 34 of the UUPA.

The definition of Right to Cultivate is the right to exploit land which is directly controlled by the State, within a certain period of time for agricultural, fishery or animal husbandry companies. The area of land that can be granted is at least 5 hectares, if the land area is above 25 hectares it requires capital investment. The term of the right to cultivate can be granted in a period of 25 to 35 years depending on the commodity being planted. It is re-described in the explanation of article 28 of the UUPA which states that, "HGU is a special right to work on land for agricultural, fishery and animal husbandry cultivation". HGU comes from land controlled by the state, with the procedure of a legal subject requesting its right to the state to manage and exploit the land in the fields of agriculture, fisheries and animal husbandry. HGU is a means provided by the state in fulfilling the needs of investors to run their business.

Referring to the Regulation of the Minister of Agrarian and Spatial Planning/ National Land Agency Number 7 of 2017 concerning Regulations and Procedures for Establishing Rights to Cultivate (hereinafter referred to as Ministerial Regulation on HGU), Submission of HGU application is carried out in several stages, namely;

1. Land parcel measurement;

2. Application for rights;

3. Land inspection;

4. Establishment of rights; and

5. Registration of rights.

Before submitting an application to obtain $\mathrm{HGU}$, the applicant is required to acquire and control the land being applied for, proven by juridical data and physical data. If the land to be applied for is attached to the rights of another legal subject, the status must first be released to become state land. The mechanism for releasing this entitled land must be accompanied by compensation for the party concerned. ${ }^{3}$ The amount of compensation given by the applicant is determined based on mutual agreement by the parties. The agreement will then be stated in the Relinquishment Deed of Rights.

In the relinquishment deed, the position of the parties is equal, even though the party requiring the land is a government agency. For, there is no compulsion in any form allowed either regarding the transfer of the land or the compensation. The amount of compensation must be determined based on mutual consent. Thus, by accepting the compensation, it means that the land owner agrees to release his land to the state. The compensation is expected to protect the previous land owner from any harm, both in the social and the economic sector. ${ }^{4}$ Providing compensation for land that has been relinquished by the old legal subject is a form of recognition and respect for rights guaranteed by the statutory regulations.

The first stage to obtain HGU is the applicant shall submit an application for measuring land parcels to the local land office in accordance with their authority. After the application is submitted, measurement and mapping will be carried out by a physical task force consisting of authorized officials of ATR/ BPN and third parties, namely licensed cadastral surveyors. The second stage is the application for rights; the applicant is fully responsible for the validity and material truth of the submitted application data. After the application documents are received by the authorized official, an investigation and examination will be carried out related to the physical and juridical data of the application. The investigation includes examining the completeness of the application documents, while examination relates to an assessment of the status of land, land's history and the legal relationship between the land being requested and the applicant as well as other interests. The third stage,

\footnotetext{
${ }^{1}$ Dyah Hapsari Praningrum, Telaah Terhadap Esensi Subjek Hukum Manusia dan Badan Hukum, Jurnal Refleksi Hukum, Vol. 8 No. 1, 2014, p. 74

${ }^{2}$ Juosfiel Sadpri Pansariang. Proses Dan Syarat Untuk Memperoleh Hak Milik Atas Tanah di Indonesia, Jurnal Lex Privatum Vol. 2 No. 3 , 2014, p 28.

${ }^{3}$ Urip Santoso, Op. Cit., p 102

${ }^{4}$ Boedi Harsono, Hukum Agraria Indonesia, Sejarah Pembentukan Undang-Undang Pokok Agraria, Isi dan Pelaksanaannya, Jilid 1, Hukum Tanah Nasional (Jakarta: Universitas Trisakti, 2018), p. 335
} 
namely land inspection, is carried out to determine whether or not land use is suitable with the Regional Spatial Planning and regional development plans. Based on this inspection, it determines whether the right to cultivate can be granted or not to a legal subject. The fourth stage concerns on the determination of rights, the right to cultivate is granted in the form of a decision to grant or refuse the right to cultivate by the National Land Agency in accordance with its authority. The authority to grant, extend or renew HGU in Article 59 of the ATR/BPN Regulation No.7 of 2017. The legal relationship between the legal subject of the right holder and the state will give rise to rights and obligations for an achievement known as an engagement. According to Subekti, cited in Wawan Muhwan Hariri, engagement is a legal relationship that arises due to a legal event which can be in the form of an act, incident, or situation. ${ }^{1}$ If it is related to obtaining the right to cultivate, then the agreement is born because of the actions of a legal subject, in this case a legal entity (company). Actions taken by legal subjects by applying for rights over a plot of land to the state to be controlled and managed, it can be ascertained that the company and the state have a legal relationship, namely as the right grantor and right receiver.

If the state approves the application submitted by a legal subject, it will issue APHT as a sign of the transfer of right originally controlled by the state is given to the legal subject as the right holder. By the transfer of these rights, it means that civil rights have been attached to legal subjects. The transfer of rights to the land object rises to a right control known as Bezit. Bezit is a condition in which a person controls an object, both movable and immovable objects, but legally, the object is not necessarily his own property. ${ }^{2}$ Bezitter (a legal subject who holds the rights) only controls objects materially, while legally the objects belong to other people.

The fifth stage is registration of rights. This stage is carried out to obtain legal certainty of the rights granted by the state as stipulated in article 19 paragraph 1 of the UUPA. It means the state guarantees legal certainty since legal subjects register their rights in the land book at the National Land Agency Office. This registration functions to facilitate land rights holders to prove their rights. For the interested parties, it is used to obtain the necessary information regarding the land which is the object of the legal action to be carried out. ${ }^{3}$ Registration of a decree of granting rights is interpreted by levering land objects from the state which are submitted to the subject of the rights holder, with such registration the right to cultivate will come into effect. As explained by Sri Soedewi, cited in the Trisadini, Levering is valid if it meets several conditions, namely;

1. The existence of an agreement causing the material rights transfer.

2. The existence of right base to transfer of the object of the agreement.

3. Entitled Authority (beschikkingsbe voegdheid)

4. Real submission and juridical submission.

First, namely the agreement causing transfers of material rights. If it is associated with submitting a HGU application, there is no agreement between the legal subject and the state, but with the issuance of a letter stipulating the granting of right to cultivate it can be interpreted that bezit has transferred to the legal subject of the applicant. The material agreement contained in book II of the Civil Code is different from the agreement contained in Book III of the Civil Code. The agreement in Book III is basically an obligatory which creates an engagement (verbintenis) between the legal subjects, while the material agreement creates a legal relationship between the legal subject and the object. Therefore, the issuance of the letter of determination to grant the right to cultivate, the legal relationship that arises is not limited to the legal subject of the applicant and the object of the application, namely land, but the obligatory legal relationship between the applicant's legal subject and the state is binding.

Second, there is a right base from the transfer of the agreement object. It concerns on a legal relationship that results in the transfer of material rights, namely an obligatory bond as stated in article 584 of the Civil Code. The legal relationship occurring because the legal subject takes legal action to appeal for his rights to the state, to obtain the validity of this right, the legal subject needs to register a letter of determination to grant rights to cultivate in the land book. Registration of these rights showed that the legal subject is willing to bind himself to the provisions referred to in the provisions of the UUPA.

Third is the Entitled Authority. Article 584 of the Civil Code defines as a result of the existence of a right base for the transfer of the agreement object, in addition to a legal title, the authority of the person who transfers it is also required as a condition for the validity of a handover. Therefore, a person cannot transfer rights beyond his owned rights. Usually the authority to move the objects is the authority of the owner, i.e., the state. Meanwhile, the requirements referred to are by registering their rights to the land book.

Fourth is real submission and juridical submission. Real submission is a handover from the old legal subject to the new legal subject. For movable objects, juridical and actual submissions are generally carried out simultaneously, whereas the stipulation on immovable objects is different. The two types of submission are separated. Juridical handover occurs when a legal subject registers a letter of determination to grant the right to

\footnotetext{
${ }^{1}$ Wawan Muhwan Hariri, Hukum Perikatan Dilengkapi Hukum Perikatan dalam Islam, (Bandung : Pustaka Setia, 2011), p 19

${ }^{2}$ Salim HS, Pengantar Hukum Perdata Terltulis (BW), (Jakarta : Sinar Grafika, 2019), p 104

${ }^{3}$ Boedi Harsono, Op. Cit., p. 472
} 
cultivate in the land book, while the actual handover is made at the time the certificate of land rights is submitted to the legal subject. If it is related to obtaining rights to cultivate by a legal subject, then the legal subject receives the rights from the state. Thus, the civil rights emerges from the legal subject.

HGU registered in the land book means that the state guarantees legal certainty for the rights granted. The guarantee of legal certainty intended to be realized in this land registration, includes: ${ }^{1}$ (1) Certainty of the status of the rights being registered. It means by registering land, the certainty of rights status registered will be known, in this case, the right to cultivate. (2) Certainty of the subject of rights, meaning that by registering the land, the holder of the rights will be known clearly, whether an individual (Indonesian citizen or foreigner domiciled in Indonesia), a group of people collectively, or a legal entity (private legal entity or legal entity). (3) Certainty of the object of rights, meaning that by registering the land, the exact location of the land, the boundaries of the land and the size (area) of the land can be ascertained.

Every land registration produces a certificate as an evidence of rights guaranteed by the law. ${ }^{2}$ The issuance of a certificate of land rights is the result of a legal event that has occurred due to a registration of rights, which of the legal events creates a legal bond between one party and another, the agreement creates rights and obligations. The state's obligation to guarantee legal certainty in this context is fulfilled by issuing securities in the form of a land rights certificate.

\subsection{Legal Consequences of Overlapping Land against Legal Subjects' Civil Rights}

Regulations related to land acquisition and ownership are regulated in the UUPA, legal subjects can have rights over land due to legal events in the form of buying and selling, hereditary or obtained by applying for their rights to the state to control and manage state land as stipulated in the statutory regulations. However, the process of obtaining land rights often violates the rights of other legal subjects, resulting in reduced land area.

Acquisition of land by legal subjects as part of civil rights can be carried out based on the provision regulated in the UUPA. ${ }^{3}$ It is in line with the principle of equality for every Indonesian citizen to have the same opportunity to obtain a right to land and to get benefits and results as stipulated in article 9 paragraph 2 of the UUPA. The use and cultivation of land with these rights not only gives the authority to work on the earth's surface, but also on the earth's body underneath it, the water and airspace above it. The phrase "to obtain benefit, both for himself and his family" denotes the individual nature of land rights. The conception of national agrarian law implies that every legal subject can control, manage and use land privately without interference from others.

The right to control land is a concrete legal relationship between land objects that are bound to each other with certain people or legal entities as subjects or holders of their rights. ${ }^{4}$ Every legal subject who applies for HGU to the state shall adhere to the civil rights of other legal subjects. In fact, legal subjects often do not understand the extent of the object and the history of the land they are petitioning for, causing problems that lead to land disputes, one of which is land overlapping. This dispute causes obstruction of access to legal subjects who have the right to use and cultivate the land

Overlapping land disputes can occur due to the wrong designation of land parcels to be applied for by the plantation company to the National Land Agency. Miss appointments made by legal subjects related to land objects to be measured can be categorized as illegal acts that have met the norms in article 1365 Civil Code. The qualification of an act committed by a legal subject contains elements of an act that violates the rights of others guaranteed by law. This right is normalized in article 4 paragraph (1) of the ATR/ BPN Regulations no. 7 of 2017 that before applying for rights, the legal subject (applicant) is required to acquire and control land as evidenced by physical data and juridical data. In fact, the applicant is often careless that the land object being petitioned for is still attached to the rights of other legal subjects. This error resulted in the issuance of a new decree of granting rights to cultivate which overlapping land rights of other legal subjects. The issuance of this decree will undoubtedly have an impact on the violation of the boundaries of the legal subject area which obscures the basis for control of land rights and creates legal uncertainty for the subject who receives rights, namely the right to fully own and receive the benefits of the land.

The Plantation companies are business entities that relies their production activities on lands. Legality of land rights is needed to ensure protection and legal certainty of land rights holders. ${ }^{5}$ Therefore, the state is obliged to assist the provision of land needed by the plantation company. Fulfilling the need for state land has in fact often hampered people's access to the land they own because it is directly adjacent to the plantation company land. These problems lead to disputes and conflicts that occur in society.

The National Agrarian Act distinguishes the substance of the meaning between conflict and dispute, as regulated in article 1 paragraph (2) and (3) ATR/BPN Ministerial Regulation Number 11 of 2016 on Land

\footnotetext{
${ }^{1}$ Ibid, p. 19

${ }^{2}$ Urip Santoso, Pendaftaran dan Peralihan Hak Atas Tanah, (Jakarta, Prenada Media Group, 2010) p. 3

${ }^{3}$ Boedi Harsono, Op. Cit, , p 18

${ }^{4}$ Ibid, p. 25

${ }^{5}$ Gunanegara, Hukum Perkebunan Sejarah dan Latar Belakangnya, (Jakarta : Adhi Sarana Nusantara, 2019), p. 143
} 
Disputes Settlement, Article 1 paragraph 2 explains that land disputes occur due to conflict in the land sector that occurs between individuals, legal entities, or institutions that do not have a broad impact. Meanwhile, Article 1 paragraph 3 explains that the land conflict occurs due to disputes between individuals, groups, organizations, legal entities, or institutions that have a tendency to have a broad impact. This explanation implies that disputes and conflicts as described in the Government Regulation indicate differences, namely disputes involving two parties, each of which has a basis for controlling land rights. Meanwhile, conflict is a further problem of disputes involving various parties.

The procedure a right to cultivate application is complicated and requires a long period of time that possibly causes violations of the rights of legal subjects. If these mistakes are not corrected immediately, it will lead to disputes, one of which is overlapping land. The characteristics of overlapping land disputes can be seen from the form, type, and characteristics. In this regard, the form can be divided into (1) civil land disputes and (2) administrative land disputes.

First, a civil land dispute is a claim for rights over land objects submitted by a person, several people, or a group of people, which is addressed to another party, through a court (district) because of a dispute. ${ }^{1}$ This dispute relates to civil rights belonging to the subject of the right as well as by other parties with an interest in the object of the right (land). The main problem is related to the certainty of land rights, which is derived from land physical data and land juridical data which is submitted by the recipient of the rights to ATR/BPN. Second, administrative land disputes or often referred to as state administrative disputes, namely disputes arising in the field of State Administration between persons or civil legal entities who feel that their interests have been harmed by the State Administration bodies or officials as a result of the issuance of state administrative decisions. The decree contains an administrative flaw in the determination or registration of land rights. The scope of this administrative flaw is further explained in Article 107 of the Regulation of the Minister of Agrarian Affairs/Head of BPN No. 9 of 1999 on Procedures for Granting and Cancellation of Rights to State Land and Management Rights.

Regarding types of disputes, overlapping rights can occur between holders: (1) Rights to Cultivate and Ownership Rights, (2) Rights to Cultivate and Rights to Cultivate (3) Rights to Cultivate and Customary Rights, (3) Rights to Cultivate and Rights of use, (4) Rights to Cultivate and Rights to Build. The characteristics of land overlapping disputes have differences, namely on the value of interests regarding the location, boundaries and area of land parcels that are recognized by one party, either those determined by ATR/BPN or those that are still in the process of determining boundaries. ${ }^{2}$ The difference is caused by a problem, namely, the land registration publication system adopted by the UUPA is a negative publication system with a positive tendency. ${ }^{3}$ Regarding the publication system, it is implied in Article 19 paragraph (2) letter c of the UUPA that "land registration includes the issuance of certificates of proof of rights, which act as a strong means of evidence." The use of the word "strong" refers to the strength of evidence produced by land registration activities. Thus, it can be interpreted that using the word "strong" does not mean that rights registration activities will produce "absolute" evidence.

Based on Article 19 paragraph 2 of the UUPA the word "strong" is a characteristic of negative publication system. ${ }^{4}$ However, the negative system used is not a pure negative system. It is also proved in Article 19 paragraph 1 of the UUPA that land registration is carried out by the government to ensure legal certainty. A certificate as a strong proof of right means that the physical data and juridical data contained in the certificate have evidence strength and must be accepted as true information, as long as it is not proven otherwise by other evidence, in the form of a certificate or other than a certificate (for example, land tax / letter c quotation). In this case, the court will decide which evidence is correct if it turns out that the physical data and juridical data contained in the certificate are untrue and purely due to an unlawful act committed by the legal subject of the applicant.

Even though the applicant's legal subject has registered his rights and obtained a HGU certificate, the certificate may still be cancelled because it contains administrative defects. However, the cancellation of the certificate does not mean eliminating or giving rise to land rights or other civil rights to the parties. It is supported by Article 26 Paragraph 3 of Ministerial Regulation on Land Dispute Settlement. Therefore, if the legal subject has met the qualifications to commit an illegal act, the offender is obliged to return the boundaries of the occupied land object, accompanied by compensation.

The reduction of land owned by legal subjects as a result of overlapping land disputes, means that land

\footnotetext{
${ }^{1}$ Nia Kurniati, Hukum Agraria Sengketa Pertanahan Penyelesaiannya Melalui Arbritase dalam Teori dan Praktik, (Bandung : Refika Aditama, 2016), p. 166

${ }^{2}$ Aprila Niravita Dan Rofi Wahanisa, Tipologi Sengketa Tanah Dan Pilihan Penyelesaiannya (Studi Pada Kantor Pertanahan Kabupaten Semarang), Jurnal Hukum Perdata, Vol. 1 No. 2, 2015, p. 79

${ }^{3}$ Alvian B. Tumbal, Tinjauan Yuridis Terhadap Kedudukan Kepemilikan Sertifikat Hak Atas Tanah Dalam Sistem Pembuktian Perdata, Jurnal Lex Privatum, Vol 6, No 7, 2018, p. 42

${ }^{4}$ Ibid, p. 42
} 
rights holders cannot fully control and manage the land they are entitled to. Actions against the law as regulated in the provisions of Article 1365 of the Civil Code require legal subjects who incur losses to provide compensation. Legal subjects who feel their rights have been violated can demand an achievement that is commensurate with an act that causes them to suffer a loss. ${ }^{1}$ Compensation for further unlawful acts can be in the form of material losses or immaterial losses.

Material loss is form of assets which includes losses suffered and also profits that should be obtained by a person. Meanwhile, immaterial losses do not lie in the realm of wealth, such as mental suffering or loss of one's life pleasures. Material compensation is based on the articles in the Civil Code which regulate compensation for default which is applied analogically to regulate immaterial compensation for acts against the law. In this regard, the person who has suffered a loss must make a detailed calculation that is estimated systematically in relation to the losses suffered and the benefits that will be obtained. ${ }^{2}$ Material loss experienced by legal subjects due to overlapping land causes a reduction in the land area of land rights holders, while the immaterial losses as causes negligent on the civil rights of the legal subject.

Basically, immaterial compensation cannot be calculated mathematically by how much money is given to compensate for the losses suffered. Therefore, the judge's discretion is needed in applying the condition that the amount of compensation must be reasonable. If it is related to land overlapping disputes, the provision of immaterial compensation is a form of respect for the civil rights of legal subjects that have been guaranteed by law. The civil rights possessed by legal subjects are very difficult to calculate. The relationship between land law and humans is not only bound from the economic side but also from the emotional side. Humans in carrying out their lives must depend on the land from birth to death, they need land, and therefore land becomes a basic need for humans. It is to make it easier to provide compensation. So that it is easier to give compensation in the form of money or return to its original state, a statement that an action is done against the law, a prohibition to do an act, or to negate something that is held against the law.

If legal subjects are willing to give up their rights, compensation can be given to the old rights holders. Relinquishment of rights is a method used to obtain collective agreement reached through deliberation. The definition of the relinquishment or transfer of land rights is regulated in article 1 point 6 of Presidential Decree Number 36 of 2005 on Land Acquisition for the Implementation of Development for Public Interest. As in buying and selling, before a legal action is taken to release the right, it needs an agreement in the form of a sale and purchase agreement between the land owner and those who need it, but buying and selling is different from the relinquishment of rights. Sale and purchase is a form of transfer of rights in which the legal act of transferring rights to the land is intentionally transferred by the land owner to another party, while relinquishing rights is carried out in order to obtain new rights. ${ }^{3}$

Relinquishment of rights can only be implemented if the party requiring the land has met the requirements as the subject of the land rights concerned. For example, a government agency or a limited liability company, in case they cannot hold property rights, so relinquishing the rights is one of the stages in the process of obtaining new rights. As a result of the relinquishment of this right, the old land rights holders will be abolished and the land object status changes to state land. The agreement regarding the provision of compensation for the handover of land rights or commonly referred to as the provision of compensation is regulated by civil law, particularly the agreement law which includes all the requirements that must be fulfilled for the validity of the agreement as regulated in article 1320 of the Civil Code.

As in the sale and purchase agreement, the position of the parties is equal, even though the party requiring the land is the government agency. There is no compulsion in any form is allowed, either regarding the transfer of the land or compensation thereof. The amount of compensation shall be determined based on mutual consent. Thus by accepting the compensation, it means that the land owner agrees to release his land to the state.

Boedi Harsono opines that by giving compensation due to act of relinquishing rights, it is expected that the former land owner does not experience any harm, both in the social and at the economic sector. ${ }^{4}$ In line with this opinion, it is not appropriate that giving rewards of land rights is called compensation, but etymologically it is more accurately described as profit, because by handing over the land from the old rights holder shall not harm their economic and social position.

In the deliberation process, the land owner cannot be forced to fulfill the subject's will for the relinquishment of rights. The Presidential Decree Number 36 of 2005 mentioned that the relinquishment agreement between parties who own the land and the government agency will be stated in the decision of the land acquisition committee. The committee shall provide an intermediary in the deliberations held, if it is a private legal entity that requires land, the agreement to relinquish its rights will be set forth in the form of a notary deed by the Land Deed Making Official. With the relinquishment of this right, the land will become the

\footnotetext{
${ }^{1}$ Rachmat Setiawan. Tinjauan Elementer Perbuatan Melawan Hukum. (Bandung: Binacipta, 1991). P. 28.

${ }^{2}$ Munir Fuady. Perbuatan Melawan Hukum: Pendekatan Kontemporer. (Bandung: Citra Aditya Bakti. 2002) p. 134.

${ }^{3}$ Boedi Harsono, Op. Cit., p. 330

${ }^{4}$ Ibid, p. 335
} 
State land, to submitted by the parties concerned for granting of new rights, for example the HGU.

\section{CONCLUSION}

Based on the above research description, the conclusions of the research are presented as follows:

1. The legal position of the legal subjects civil rights due to overlapping land on an object (land) obtained from the state will not be lost. In essence, civil rights will always be attached to legal subjects since the issuance of the decision to grant rights. So that the civil rights of legal subjects have juridical power to control objects, it is proven by a Decree of Granting Rights. However, overlapping lands on legal object controlled by a legal subject who already has civil rights over the object shows position of the legal subject's civil rights cannot be ignored. Legal subjects who obtain civil rights are required to register their rights at the competent institution, i.e., the BPN. Registration is carried out to provide a guarantee of legal certainty as evidenced by HGU Certificate as evidence of land rights. However, the absence of norms in the Regulation of the Minister of Agrarian and Spatial Planning/Head of the National Land Agency Number 7 of 2017 on Arrangements and Procedures for Establishing Rights to Cultivate, namely there is no time limit regarding the applicant's obligation to register his rights after obtaining a decision to determine rights until the issuance of a HGU certificate causes Legal subjects negligence by not registering their rights. This fact causes difficulties for legal protection to run optimally.

2. The legal consequence of overlapping land against civil rights owned by legal subjects results in disputes that can lead to reduced and/or loss of land controlled and managed by rights holders. Land overlapping disputes originated from an illegal act committed by the applicant due to an error in the designation of the object and the boundaries of the land object, which caused violation of the civil rights of other legal subjects who have previously controlled and managed the land. The unlawful act committed by the other party has the implication that the party is obliged to provide compensation to the legal subject who has been injured, as a form of recognition and respect for rights guaranteed by the statutory regulations.

\section{SUGGESTIONS}

Based on the problems and conclusions that have been stated above, suggestions can be given, as follows:

1. That the Ministry of Agrarian Affairs and Spatial Planning/National Land Agency shall evaluate the Regulation of the Minister of Agrarian and Spatial Planning/Head of the National Land Agency of the Republic of Indonesia Number 7 of 2017 on Regulations and Procedures for Determining Rights to Cultivate due to the absence of specific regulation on time boundaries for the recipient of the right to register until the issuance of the certificate of land rights. Thus, the authors suggest an addition of norms constructed in one article, which are as follows:

Article 28A

(1) Within a period of 1 (one) year from the issuance of Decree of Granting Rights, recipient is obligatory to certify the rights on the land he received.

(2) If the recipient of land rights does not implement what is meant in paragraph (1), the Decree of Granting Rights may be evaluated and canceled.

The construction of these norms serves as a basis for policy holders in identifying, evaluating and supervising land rights recipients to comply with the decrees issued by the government. Furthermore, it is to minimize the violation of rights obtained and improve the system at the National Land Agency.

2. If a legal subject committed an unlawful act, he is obliged to return the boundaries of the occupied land object by providing compensation or taking over the right over the land object by the process of sale and purchase. It is proven by the existence of supervision and a statement letter from the National Land Agency on the course of providing the compensation.

\section{REFERENCES}

\section{A. Books}

Bachtiar Efendie. 1993. Kumpulan Tulisan Tentang Hukum Tanah. Bandung: Alumni.

Boedi Harsono. 2018. Hukum Agraria Indonesia, Sejarah Pembentukan Undang-Undang Pokok Agraria, Isi dan Pelaksanaannya,, Jilid 1, Hukum Tanah Nasional. Jakarta: Universitas Trisakti.

Gunanegara, 2019. Hukum Perkebunan Sejarah dan Latar Belakangnya. Jakarta : Adhi Sarana Nusantara.

Havidz Rizky. 2018. Skripsi: Faktor-Faktor Terjadinya Tumpang Tindih Sertipikat Hak Atas Tanah Dalam

Pendaftaran Tanah Di Kabupaten Sukoharjo Yogyakarta: Program Sarjama Fakultas Hukum Universitas Islam Indonesia.

Munir Fuady. 2002. Perbuatan Melawan Hukum: Pendekatan Kontemporer. Bandung: Citra Aditya Bakti.

Nia Kurniati. 2016. Hukum Agraria Sengketa Pertanahan Penyelesaiannya melalui Arbritase Dalam Teori dan 
Praktik. Bandung: Refika Aditama.

Rachmadi Usman. 2011. Hukum Kebendaan. Jakarta: Sinar Grafika.

Rachmat Setiawan. 1991. Tinjauan Elementer Perbuatan Melawan Hukum. Bandung: Binacipta.

Rusmadi Murad. 2013. Administrasi Pertanahan, Pelaksanaan Hukum Pertanahan Dalam Praktek. Bandung: Mandar Maju.

Salim HS. 2019. Pengantar Hukum Perdata Terltulis (BW), Jakarta : Sinar Grafika.

Urip Santoso. 2013. Hukum Agraria Kajian Komperhensif. Surabaya: Kencana. . 2010. Pendaftaran dan Peralihan Hak Atas Tanah. Jakarta, Prenada Media Group.

$\overline{\text { Wawan }} \overline{-}$ uhwan Hariri. 2011. Hukum Perikatan Dilengkapi Hukum Perikatan dalam Islam, Bandung : Pustaka Setia.

\section{B. Journals}

Alvian B. Tumbal, Tinjauan Yuridis Terhadap Kedudukan Kepemilikan Sertifikat Hak Atas Tanah Dalam Sistem Pembuktian Perdata, Jurnal Lex Privatum, Vol 6, No 7, 2018.

Aprila Niravita Dan Rofi Wahanisa, Tipologi Sengketa Tanah Dan Pilihan Penyelesaiannya (Studi Pada Kantor Pertanahan Kabupaten Semarang), Jurnal Hukum Perdata, Vol. 1 No. 2, 2015.

Ari Hernawan. Keseimbangan Hak dan Kewajiban Pekerja dan Pengusaha dalam Mogok Kerja, Jurnal Mimbar Hukum Vol. 24 No. 3, 2012.

Dyah Hapsari Praningrum, Telaah Terhadap Esensi Subjek Hukum Manusia dan Badan Hukum, Jurnal Refleksi Hukum, Vol. 8 No. 1, 2014.

Haposan Siallagan, Penerapan Prinsip Negara Hukum di Indonesia, Jurnal Sosiohumaniora, Vol. 18 No. $2,2016$.

Khathryna Ihcent Pelealu, Konsep Pemikiran Tentang Negara Hukum Demokrasi dan Hukum Hak Asasi Manusia Pasca Reformasi, Jurnal Lex Administratum, Vol. 3 No. 7, 2015.

Jeffry Alexander Ch. Likadja, Memaknai "Hukum Negara (Law Through State)” dalam Bingkai” Negara Hukum (Rechtstaat)". Jurnal Hassanudin Law Review, Vol 1 No. 1, 2016.

Juosfiel Sadpri Pansariang. Proses Dan Syarat Untuk Memperoleh Hak Milik Atas Tanah di Indonesia, Jurnal Lex Privatum Vol. 2 No. 3, 2014.

\section{Legislations}

Government Regulation number 40 of 1996 on Right to Cultivate, Right to Build, and Right to Use Land (the State Gazette of the Republic of Indonesia number 58 of 1996, addition to the state gazette of the Republic of Indonesia number 3643).

The Civil Code

The Ministry of Agrarian Affairs/ National Land Agency Regulations number 11 of 2016 on Land Dispute Settlement (the State Gazette of the Republic of Indonesia number 569).

The Ministry of Agrarian Affairs/ National Land Agency Regulations number 7 of 2017 on Regulations and Procedures for Establishing Rights to Cultivate the State Gazette of the Republic of Indonesia number 965 of 2017).

The Presidential Decree number 36 of 2005 Land Acquisition for the Implementation of Development for Public Interest

\section{Web Article}

Ratna Puspita, 2019, KSP Terima $\quad$ Laporan $780 \quad$ Kasus $\begin{aligned} & \text { Sengketa } \\ & \text { Tanah, }\end{aligned}$ on February 2, 2020 at $02.00 \mathrm{pm}$ ) 